\title{
SURVIVAL MECHANISM OF THE SHIA COMMUNITY POST- SHIA-SUNNI SAMPANG CONFLICT IN 2012
}

\author{
Muhammad Aziz Khoiri, Leila Chamankhah \\ Universitas Airlangga, Surabaya Indonesia \\ Department of Philosophy, University of Dayton, United States \\ azizkhoiri@live.com
}

Received: 20-03-2021 Revised: 17-06-2021 Accepted: 06-09-2021

\begin{abstract}
The purpose of this article is to discuss the mechanisms that the Shia community of Rusunnawa Puspa Agro Sidoarjo adopted to survive the sectarian conflict of 2012. This research uses a qualitative approach, using a snowball sampling technique with key informants, Ustad Tajul Muluk and Ustad Iklil. Data collection techniques include in-depth interviews. The result is indicative of the fact that the Shia community took three approaches to survive the sectarian clashes. First, the Shia community attempted to reduce its daily expenses to the most urgent needs. Second, the Shia community members used an alternative subsystem of working as coconut shelling labor, farming the surrounding land, and raising goats and chickens to help meet their daily needs. Third, the Shia community members got a governmental network in the form of jadup money, ${ }^{1}$ in the form of the patron-client relationship. This research also shows that the Shia community needs to get social support because material assistance is not enough.
\end{abstract}

Keywords: Conflict, Survival Mechanism, Shia-Sunni, Sampang

\section{Abstrak}

Tujuan artikel ini adalah mendeskripsikan mekanisme bertahan bidup (survival mechanism) pada komunitas Syi'ah pasca Konflik tahun 2012 di Rusunnawa Puspa Agro Sidoarjo. Penelitian ini menggunakan pendekatan kualitatif. Menggunakan teknik snowball sampling dengan informan kunci Ustad Tajul Muluk dan Ustad Iklil. Teknik pengumpulan data menggunakan wawancara mendalam. Hasil dari penelitian ini menunjukkan bawa ada 3 cara bertahan bidup yang dilakukan

1 - Jadup is the acronym of jatah hidup, and Jatah is a financial help which is either provided by the government, or parents, or even one's boss, but not because one has done something, but rather, because it is part of one's right. 
Komunitas Syiah : Pertama, komunitas Syi'ah mengurangi biaya pengeluaran seharihari untuk biaya kebutuban penting lainnya. Kedua, komunitas Syi'ah menggunakan alternatif subsistem berupa menjadi burub pengupas kelapa, bercocok tanam di lahan sekitar, beternak kambing dan ayam untuk membantu memenubi kebutuban seharibari. Ketiga, komunitas Syi;ah mendapatkan jaringan sosial pemerintah berupa uang jadup (Jaminan bidup) dalam hal ini pemerintab adalab patron yang memberikan pelindungan terhadap komunitas Syi'ab yang dalam hal ini adalah klien. Penelitian ini juga menunjukkan komunitas Syi'ah perlu mendapatkan dukungan sosial (social support) karena bantuan yang sifatnya material tidak cukup.

Kata Kunci : Konflik, Mekanisme Survival, Syi'ah-Sunni, Sampang

\section{INTRODUCTION}

The Shia-Sunni conflict of August 26, 2012 in Sampang, still draws the attention of scholars and policy makers, because neither the roots of the conflict nor the remaining wounds have been resolved yet. According to Kontras Surabaya's report, the Shi'a Community still occupies the Rusunnawa Puspa Agro Sidoarjo, which was originally intended as a temporary relocation, and until now, the Shia Community still occupies the Rusunnawa Puspa Agro Sidoarjo ${ }^{2}$. This conflict began when 20 Shi'a children were about to return to the Islamic boarding school (Pesantren) outside Sampang, but in the middle of the road the group of students was blocked by dozens of people who claimed to be Sunnis. The group of Shia students finally returned home and there was a commotion that ended in a fight that killed one victim ${ }^{34}$.

The conflict that broke out in 2012 was caused by many factors, one of which was a family conflict represented by Tajul Muluk (Shia) and Roisul Hukami (Sunni). Both of them are brothers from Kyai Ma'mun and Ummah's parents $^{5}$. The figure of Halimah, a student from Rois, who was not married to Rois because Tajul helped his friend to propose to Halimah, made Rois angry with Tajul. Later it was found out that Rois liked Halimah and wanted to marry

${ }^{2}$ Kontras Surabaya. "Laporan Investigasi dan Pemantauan Kasus Syi’ah Sampang”. (Surabaya, 2012)

326 Agustus 2012: Lebaran Berdarah Warga Syiah di Sampang Madura. (Jakarta, 2019). https://www.liputan6.com/news/read/4046654/26-agustus-2012-lebaran-berdarah-warga-syiah-di-sampangmadura

${ }^{4}$ Ahmad Zainal Abidin et al., "Between Conflict and Peace: The Government Policies and Sunni-Shia Relationship in Sampang and Yogyakarta," ESENSLA: Jurnal Ilmu-Ilmu Ushuluddin 21, no. 2 (2020): 135-50.

${ }^{5}$ Neneng Sobibatu Rohmah, "Identity Politics and National Integration; A Case Study of the Sunni-Shia Conflict in Sampang, 2012," International Journal of Interreligious and Intercultural Studies 4, no. 1 (June 19, 2021): 96108, https://doi.org/10.32795/ijiis.vol4.iss1.2021.1076. 
him, and since that incident Rois left the Shia and returned to Sunni and aggressively vilified the Shia. ${ }^{6}$

The bloody conflict described above is the culmination of a series of events that accompany it on a small and limited scale. The 2012 conflict seems to stem from the government's failure to resolve conflicts that have been emerging since the early $2000 s^{7}$. In the report of the Pesantren for Peace, it was noted that there were fifteen meetings held by various parties, including the Sampang government ${ }^{8}$. The conflict began with the disagreement of two figures who were cousins of Kyai Ma'mun (Shia) and Kyai Karrar (Sunni), which continued to his son Kyai Ma'mun. Tajul Muluk against Kyai Karrar became a triangle of Tajul Mulul, Kyai Karrar and Roisul Hukama?. The conflicts are increasingly complicated and escalating, in addition to the expansion of Shi'ite da'wah, social balance, struggles for santrit ${ }^{10}$ and authority, family conflicts and so on. One thing is certain: the conflict started from a form of intolerance towards differences in understanding, then it expanded not only to involve Kyak Ma'mun, Kyai Karrar and Tajul Muluk, but to involve supporters of each group ${ }^{11}$

After the conflict that occurred in Nang Kenang Hamlet, Karanggayam Village, Omben District and Blu'uran Village, Karang Penang District, Sampang Regency, between the Sunni group and the Shi'a Community, the Shia community was finally relocated to Sampang Sports Center. At Sampang Sports Center, a closed circular building, refugees sleep on mats and makeshift carpets. Many of the Shia Community also sleep on cardboard ${ }^{12}$. According to official

${ }^{6}$ The Asian Moslem Action Network Indonesia. Dilema Kebebasan Beragama di Indonesia : Studi Kasus Pembakaran Rumah Ibadab di Sampang Madura. (2012). 21.

${ }^{7}$ Raza A. Mir, "Religion as a Coping Mechanism for Global Labor: Lessons from the South Asian Shia Muslim Diaspora in the US," ed. Jawad Syed and Edwina Pio, Equality, Diversity and Inclusion: An International Journal 32, no. 3 (January 1, 2013): 325-37, https://doi.org/10.1108/EDI-12-2012-0111.

8 Rachmah Ida and Laurentius Dyson, "Konflik Sunni-Syiah Dan Dampaknya Terhadap Komunikasi Intra-Religius Pada Komunitas Di Sampang-Madura," Masyarakat, Kebudayaan Dan Politik 28, no. 1 (2015): 33-49; Syukron Mahbub, "Konflik Dan Kekerasan Sunni-Syiah Sampang Prespektif Kultur Kekerasan Dan Hak Asasi Manusia," Voice Justisia: Jurnal Hukum Dan Keadilan 2, no. 1 (2018): 92-101; Nour Zattullah, "Konflik Sunni-Syiah Di Sampang Ditinjau Dari Teori Segitiga Konflik Johan Galtung," Jurnal Ilmu Budaya 9, no. 1 (2021): 86-101.

9 Rachmah Ida and Muhammad Saud, "The Narratives of Shia Madurese Displaced Women on Their Religious Identity and Gender Citizenship: A Study of Women and Shi'as in Indonesia," Journal of Religion and Health 60, no. 3 (2021): 1952-68.

${ }^{10}$ The Santri are people in Javanese who practice a more orthodox version of Islam. in this paper, by Santri we mean an Islamic Student in The Boarding School (Pesantren).

11 Mohamad Nabil, Laporan Penelitian : Konflik Syi'ah - Sunni Sampang : Jalan Terjal Menuju Rekonsiliasi. (2012). 3.

12 A'an Suryana, "State Officials' Entanglement with Vigilante Groups in Violence against Ahmadiyah and Shi'a Communities in Indonesia," Asian Studies Review 43, no. 3 (July 3, 2019): 475-92, https://doi.org/10.1080/10357823.2019.1633273; Fatemeh Marashian and Elahe Esmaili, "Relationship Between Religious Beliefs of Students with Mental Health Disorders Among the Students of Islamic Azad 
records, as many as 584 Shi'a communities, or 135 families, only 306 people were evacuated to Sampang Sports Center, which were mostly women, children, infants and toddlers. ${ }^{13}$

According to Tempo daily, the Shia community was then relocated outside Madura, in Rusunnawa Puspa Agro, Jemundo Village, Taman District, Sidoarjo Regency. Rusunnawa Puspa Agro is used as a temporary relocation place for victims of the Shi'a-Sunni conflict in Sampang, this is because reconciliation has not been achieved from both parties. According to the author's notes in the discussion of five years of advocacy for Sampang Shia refugees held at the Kontras Surabaya Office, they received information that there were about 336 Sampang Shia refugees and about 81 heads of families. ${ }^{14}$

While in Rusunnawa Puspa Agro Sidoarjo, the Shia refugees did various activities to meet their daily needs, and this is done because of the insufficient life security deposit. In addition, there are also those who work as satay craftsmen, grow tobacco around Rusunnawa, and raise goats. James Scott has explained how one can survive in such a situation. ${ }^{15} \mathrm{He}$ discusses three ways by which the vulnerable adopt to survive, including reducing food expenditure by eating only once a day and switching to lower quality food, and using other alternatives to meet their needs, such as small-scale businesses, working as a handyman or laborer and migrating to find work, and asking for help from social networks using relationships with their patrons.

Survival Mechanism was addressed by Cholicul Hadi et al's (2017) research entitled Survival Mechanism for the Percatu Tulungagung Community, in which the Percatu Community adopted three approaches to be able to live a precarious circumstances. First, people with physical disabilities reduced their daily expenses, including spending on medicines and using mobile devices. People with physical disabilities create small businesses at home, and finally, people with physical disabilities ask for help from official networks and resources. ${ }^{16}$ Along

University of Ahvaz," Procedia - Social and Behavioral Sciences, 4th WORLD CONFERENCE ON EDUCATIONAL SCIENCES (WCES-2012) 02-05 February 2012 Barcelona, Spain, 46 (January 1, 2012): 1831-33, https://doi.org/10.1016/j.sbspro.2012.05.387.

${ }^{13}$ Kontras Surabaya. "Laporan Investigasi dan Pemantauan Kasus Syi'ah Sampang”. (Surabaya, 2012) 11.

${ }^{14}$ Diskusi 5 Tahun Advokasi Pengungsi Syi’ah Sampang. (Surabaya, 2017)

15 James C. Scott, Moral Ekonomi Petani: Pergolakan Dan Subsistensi Di Asia Tenggara / James C. Scott; Diterjemahkan Oleh Hasan Basari; Disunting Oleh Bur Rasuanto (Jakarta: LP3ES, 1983).

${ }^{16}$ Cholichul Hadi and Femita Adelina, "Mekanisme Bertahan Hidup (Survival Mechanism) Komunitas Percatu Tulungagung," accessed August 2021, https://www.academia.edu/36669540/Mekanisme_Bertahan_Hidup_Survival_Mechanism_Komunitas_Percatu _Tulungagung; Heri Surya Nugraha, "Mekanisme Survival Petani Perkotaan (Studi Deskriptif Tentang Strategi Bertahan Hidup Petani Di Kelurahan Made, Surabaya)" (PhD Thesis, UNIVERSITAS AIRLANGGA, 2015). 
with the above-mentioned sources, other research also testifies to the same approaches, which a community chooses to meet its needs and survive a rough situation. ${ }^{17}$

\section{METHODS}

In this study, we focused on the Shia Community after its relocation in Rusunnawa Puspa Agro, located in Jemundo Village, Taman District of Sidoarjo Regency. Using a qualitative approach, we were able to obtain data through direct observation as well as face-to-face interviews with a member of the Shia community who had experienced the sectarian clash of 2012. In order to analyze the data, we used Snowball Sampling with key informants Ustad' ${ }^{18}$ Tajul Muluk and Ustad Iklil, the leader of the Shia community. From the explanation of the key informant, we moved on to other informants to verify the veracity of the data to see if they are valid.

Data analysis was carried out during the study, to ensure that special attention had been paid to research during the in-depth interview process, as well as to ensure the qualitative analyzation of the data. Data analysis was carried out during and after field work. Data were taken through in-depth interviews and based on field observations. After the data is obtained and it is deemed sufficient, the researcher then examines and selects the data according to the research focus. Reduction is done in order to clarify to the reader an understanding of the data obtained as well as to offer a "clearer" picture in the filed. Data analysis uses interactive models, namely data reduction, data presentation, and research conclusions (verification). ${ }^{19}$

\section{RESULT AND DISCUSSION}

The Survival Mechanism Theory was popularized by James Scott, who elucidates how farmers strive to survive for years without sources of income or crops that are not sufficient for their daily needs. Scott explained that there are three ways that farmers reduce spending on food by eating once a day and

${ }_{17}$ Nia Kumalasari, "Komunikasi Ibu Pada Anak Mengenai Konflik Pada Survivor Komunitas Syiah Sampang Madura" (PhD Thesis, Universitas Islam Negeri Maulana Malik Ibrahim, 2014); Hanggarbini Sapta Wisuda Yanto, "Dampak Konflik Antar Aliran Agama (Studi Deskriptif Tentang Mekanisme Survival Para Pengungsi Keluarga Syiah Dalam Memenuhi Kehidupan Di Kabupaten Sampang)," n.d.; Abd Aziz and Matnin Matnin, "Jurnalis Dalam Tinjauan Sosial Ekonomi Politik Pada Konflik Sunni-Syiah Di Kabupaten Sampang," KABILAH: Journal of Social Community 3, no. 2 (2018): 223-40.

18 Teacher in Islamic Boarding School (Pesantren)

19 Sugiyono, Metode penelitian pendidikan: (pendekatan kuantitatif, kualitatif dan R \& D) (Bandung: Alfabeta, 2008); John W. Creswell, Qualitative Inquiry \& Research Design: Choosing among Five Approaches, 2nd ed (Thousand Oaks: Sage Publications, 2007). 
switching to lower quality foods, using other alternatives with small businesses around the house, and asking for help from their social networks such as relatives, family, neighbors or government. ${ }^{20}$ Furthermore, Scott explains that in a patron-client relationship, i.e., a relationship between two parties involving friendship and affinity, the patron who enjoys a higher social status uses its influence and resources to provide protection and benefits to the lower status party or client. This relationship is reciprocal, the client compensates by providing support and assistance, including services and services to parties who have a higher social status or patron. ${ }^{21}$

Scott's research explains how individuals are able to survive in difficult conditions, especially in farms. A similar condition was experienced by the members of a Shia community who were the victims of the Shia-Sunni conflict in Sampang, and made them relocate to a new place in Rusunnawa Puspa Agro Sidoarjo, which was not their native land ${ }^{22}$.

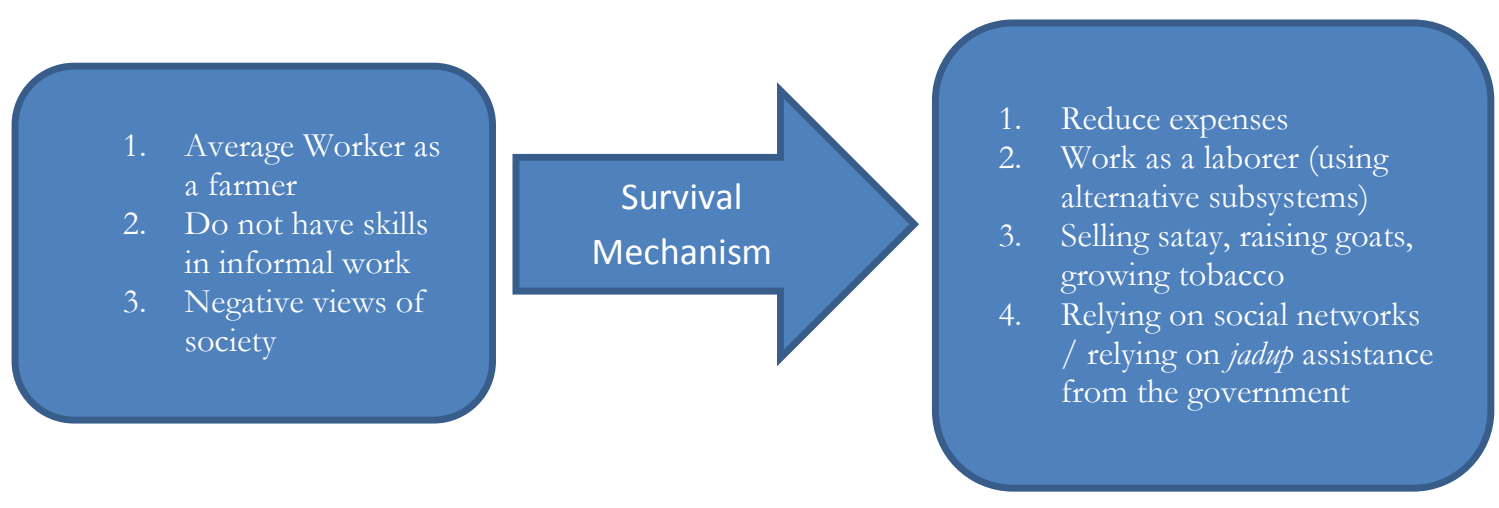

Figure 1. Survival Mechanism Sunni-Shia Sampang, Indonesia

Since relocating to Rusunawa Puspa Agro Sidoarjo, the Shia Community has been provided with assistance by the provincial government in the form of jadup amounting to 709,000 Rupiah. However, since this amount was not

${ }^{20}$ Scott, Moral Ekonomi Petani, 16.

${ }^{21}$ Professor James C. Scott, Agrarian Studies: Synthetic Work at the Cutting Edge (Yale University Press, 2001); Scott.

22 James C. Scott, Senjatanya orang-orang yang kalah: bentuk-bentuk perlawanan sehari-hari kaum tani (Jakarta: Yayasan Obor Indonesia, 2000); James C. Scott, The Moral Economy of the Peasant: Rebellion and Subsistence in Southeast Asia (Yale University Press, 1977). 
enough to cover the needs of the family, the Shia refugees tried to make as much savings as they could. As Ustad Iklil, one of our interviewees ascertains:

"If you ask if it's sufficient, actually it's not enough, actually, I'm sure that the government doesn't always provide support for our living expenses and if this can't be finished, it's clear that even though we have a small amount of savings, it's not enough to fulfill our lives because we have to pay for electricity while my own son is. The one here is the same as the one there, I have 8 dependents and that is the monthly SPP I have to pay, actually it's not enough for now even though there is a jadup". 23

Given this, the members tried to shrink their expenses in food and drink as well as other necessary payments such as the kid's schoolings.

\section{Using Subsystem Alternatives}

Due to their lower educational background and the existence of the systematic discrimination against them, the members of the Shia community were not able to find decent jobs, therefore, the only possibility was to go for humble occupations such as coconut peeling. As Ustad Iklil puts it well:

"All farmers, why is this a burden on us, bro, because they are not educated, they can only work on land, and have to live in the city, if this assistance is still available, if there is nothing we want to do, want to trade, we don't even have capital. If you have capital, you don't have that skill, maybe the young people can still do it, but it's only a little, the average here is over 50 years." 24

Another interviewee, Ustad Tajul Muluk, also confirms her peer's statement: "It's just workers, if they are there, they are coconut peeling workers in the market, sometimes they are picked up sometimes (if there's not, how about sir?) If not, then shut up". ${ }^{25}$

According to further explanation, in a day the refugees who become coconut peeler workers can peel 200-400 coconuts with an income of Rp.150

${ }^{23}$ Ustad Iklil, wawancara, Sidoarjo tanggal 14 Juni 2020

24 ibid

${ }^{25}$ Ustad Tajul Muluk, Wawancara. Sidoarjo tanggal 14 Juni 2020 
per one coconut, with an average income of being a coconut peeler worker of around Rp. 40,000-60,000 per day. This additional income certainly makes the Shia community able to survive for 8 years in Rusunnawa Puspa Agro.

To become a coconut peeler, members of the Shia community must search for the job themselves: there is no government intervention in finding side jobs for the Shia community. The job of being a coconut peeler is also the only source of income that the Shia community relies on, even if there is no coconut peeled by the Shia community, there is no other job".

Raising livestock is also an alternative for the Shia community so that they can gradually live in Rusunnawa Puspa Agro. The Shia community uses the land around Rusunnawa to raise goats and chickens.

The conflict has indeed eliminated the main livelihood of the Shia community, especially farmers. However, while in Rusunnawa, the Shi'a Community also cultivates by planting tobacco around the Rusunnawa Puspa Agro. Apart from being a means to meet daily needs, farming is also done to relieve the boredom of the Shia Community. As stated by Ustad Iklil: 'Yes, if there is nothing, so to eliminate the boredom of growing tobacco. ${ }^{26}$ The process of cultivating tobacco relieves the Shia community of boredom when there is no other work, or coconut to be peeled.

\section{Relying on Social Networks}

In addition to the abovementioned resources, the members also relied on financial help from the government in the form of jadup, or life insurance, which was endowed to them from the provincial government after they were relocated in Rusunnawa Puspa Agro Sidoarjo. As a result, all residents who have a Family Card document get jadup money of Rp. 709,000 per year. Although it should be added that even this money does not make their life more comfortable, because it does not cover all their expenses. As Ustad Iklil says:

"Previous years only per family. And some of the children who are outside the flats cannot get from the 2014 2015, 2016 budget, our children who are outside cannot afford living expenses even though the large ones are outside their tuition fees for their living needs. Only mid 2016 budget and up to this moment everything in our KK gets jadup". ${ }^{27}$ 
Reviewing James C. Scott's theory of subsistence ethics, or the mechanism carried out by farmers when they experience an economic crisis, there are three approaches implemented by poor farmers to survive the abnormal situation. These approaches include "tightening the belt", using alternative substensions or having a side job, and expanding their networks. ${ }^{28}$ The survival mechanism is not only carried out by farmers who go through economic difficulties but is also conducted by several layers of society who undergo the same experience. ${ }^{29}$

Implementing Scott's theory through our research, we observe that the members of the Shia community tested all these three approaches in coping with the difficulty of a new life after relocation. This is done because their main income is from government assistance in the form of jadup money of around 700 thousand for the needs of 1 family.

However, another strategy, i.e., reducing the quality of daily food, was difficult, although due to compulsion and the crush of the economy, they accustomed themselves to this reduction. According to one informant, reducing expenses and sharing food could save money, and that is why restricting monthly expenses to the most urgent needs such as food and schooling helped them to save money ${ }^{30}$.

Pertinent to this is having a side job, such as starting a small local business or making handicrafts as a source of extra income. Since the jadup being paid by the government was not enough, the members had to try different jobs in order to cover their expenses. However, due to a lack of skills and a low educational level, their options were only limited to humble jobs and insufficient income.

According to Edi Suharto, survival strategy is a person's ability to apply a set of ways to overcome problems. Suharto calls these strategies, which are divided into active, passive and network strategies, 'coping strategies', which maximize the ability of family members to manage their new situation. We

28 Ambayu Sofya Yuana, Siti Kholifah, and Mohamad Anas, “Mekanisme Survival Petani 'Gurem' Pada Masa Pandemi COVID-19," JSW (Jurnal Sosiologi Walisongo) 4, no. 2 (2020): 201-14; W. Widiyanto, Arya Hadi Dharmawan, and W. Nuraini, "Strategi Nafkah Rumahtangga Petani Tembakau Di Lereng Gunung Sumbing: Studi Kasus Di Desa Wonotirto Dan Desa Campursari, Kecamatan Bulu, Kabupaten Temanggung," Sodality: Jurnal Sosiologi Pedesaan 4, no. 1 (2010); Heri Surya Nugraha, "Strategi Bertahan Hidup Petani Di Kelurahan Made Surabaya," Komunitas 4, no. 3 (2015): 1-10.

29 Hadi and Adelina, "Mekanisme Bertahan Hidup (Survival Mechanism) Komunitas Percatu Tulungagung."

${ }^{30}$ Ken Miichi and Yuka Kayane, "The Politics of Religious Pluralism in Indonesia: The Shi'a Response to the Sampang Incidents of 2011-12," TRaNS: Trans-Regional and-National Studies of Southeast Asia 8, no. 1 (May 2020): 51-64, https://doi.org/10.1017/trn.2019.12. 
observed how the members of the Shia community utilized these three strategies to overcome the hardship of life in Rusunnawa Puspa Agro. Their active strategy was to extend working hours and do whatever it takes to make ends meet and increase their income. While their passive and network strategies were to reduce family expenses and to reach out to official sources of help such as jadup, respectively. ${ }^{31}$

The Shia community in Rusunnawa Puspa Agro organizes activities, such as congregations, recitations and others, that are carried out in group. Religious activities are important to take part in, in order to reduce fatigue and stress during the Rusunnawa. This allows them to survive in Rusunnawa Puspa Agro after their relocation in 2013. In other words, according to Dorfman, social support is needed by the Shia community. This support can reduce psychological distress that arises after trauma. ${ }^{32}$

\section{CONCLUSION}

From the results of the study, it can be concluded that the Shia community succeeded in improving the survival mechanism after being relocated in the Rusunnawa Puspa Agro Sidoarjo in 2013. Second, the Shia community uses alternative subsystems in the form of working as coconut peelers, farming in the surrounding land, and raising goats and chickens to help meet their daily needs. Third, the Shia community receives government aid in the form of jadup money. In this case, the government is the patron who provides protection to the Shia community, the client.

\section{REFERENCES}

Abidin, Ahmad Zainal, Imam Fuadi, Nur Kholis, and Thoriqul Aziz. "Between Conflict and Peace: The Government Policies and Sunni-Shia Relationship in Sampang and Yogyakarta." ESENSLA: Jurnal Ilmu-Ilmu Ushuluddin 21, no. 2 (2020): 135-50.

Aziz, Abd, and Matnin Matnin. "Jurnalis Dalam Tinjauan Sosial Ekonomi Politik Pada Konflik SunniSyiah Di Kabupaten Sampang." KABIL AH: Journal of Social Community 3, no. 2 (2018): 223-40.

Creswell, John W. Qualitative Inquiry \& Research Design: Choosing among Five Approaches. 2nd ed. Thousand Oaks: Sage Publications, 2007.

Dorfman, Caroline Susan. Social Support, Health, and Recurrent Breast Cancer: Understanding Psychological and Biological Mechanisms. The Ohio State University, 2015.

31 Edi Suharto, Kemiskinan Dan Perlindungan Sosial Di Indonesia: Menggagas Model Jaminan Sosial Universal Bidang Kesehatan, Cet. 1 (Bandung: Alfabeta, 2009).

32 Caroline Susan Dorfman, Social Support, Health, and Recurrent Breast Cancer: Understanding Psychological and Biological Mechanisms (The Ohio State University, 2015). 
Hadi, Cholichul, and Femita Adelina. "Mekanisme Bertahan Hidup (Survival Mechanism) Komunitas Percatu Tulungagung." Accessed August 2021. https://www.academia.edu/36669540/Mekanisme_Bertahan_Hidup_Survival_Mechanism_K omunitas_Percatu_Tulungagung.

Ida, Rachmah, and Laurentius Dyson. "Konflik Sunni-Syiah Dan Dampaknya Terhadap Komunikasi Intra-Religius Pada Komunitas Di Sampang-Madura." Masyarakat, Kebudayaan Dan Politik 28, no. 1 (2015): 33-49.

Ida, Rachmah, and Muhammad Saud. "The Narratives of Shia Madurese Displaced Women on Their Religious Identity and Gender Citizenship: A Study of Women and Shi'as in Indonesia." Journal of Religion and Health 60, no. 3 (2021): 1952-68.

Kumalasari, Nia. "Komunikasi Ibu Pada Anak Mengenai Konflik Pada Survivor Komunitas Syiah Sampang Madura." PhD Thesis, Universitas Islam Negeri Maulana Malik Ibrahim, 2014.

Mahbub, Syukron. "Konflik Dan Kekerasan Sunni-Syiah Sampang Prespektif Kultur Kekerasan Dan Hak Asasi Manusia.” Voice Justisia: Jurnal Hukum Dan Keadilan 2, no. 1 (2018): 92-101.

Marashian, Fatemeh, and Elahe Esmaili. "Relationship Between Religious Beliefs of Students with Mental Health Disorders Among the Students of Islamic Azad University of Ahvaz." Procedia Social and Behavioral Sciences, 4th WORLD CONFERENCE ON EDUCATIONAL SCIENCES (WCES-2012) 02-05 February 2012 Barcelona, Spain, 46 (January 1, 2012): 183133. https://doi.org/10.1016/j.sbspro.2012.05.387.

Miichi, Ken, and Yuka Kayane. "The Politics of Religious Pluralism in Indonesia: The Shi'a Response to the Sampang Incidents of 2011-12." TRaNS: Trans-Regional and-National Studies of Southeast Asia 8, no. 1 (May 2020): 51-64. https://doi.org/10.1017/trn.2019.12.

Mir, Raza A. "Religion as a Coping Mechanism for Global Labor: Lessons from the South Asian Shia Muslim Diaspora in the US." Edited by Jawad Syed and Edwina Pio. Equality, Diversity and Inclusion: An International Journal 32, no. 3 (January 1, 2013): 325-37. https://doi.org/10.1108/EDI-12-2012-0111.

Nugraha, Heri Surya. "Mekanisme Survival Petani Perkotaan (Studi Deskriptif Tentang Strategi Bertahan Hidup Petani Di Kelurahan Made, Surabaya)." PhD Thesis, UNIVERSITAS AIRLANGGA, 2015.

. "Strategi Bertahan Hidup Petani Di Kelurahan Made Surabaya." Komunitas 4, no. 3 (2015): 110 .

Rohmah, Neneng Sobibatu. "Identity Politics and National Integration; A Case Study of the SunniShia Conflict in Sampang, 2012." International Journal of Interreligious and Intercultural Studies 4, no. 1 (June 19, 2021): 96-108. https://doi.org/10.32795/ijiis.vol4.iss1.2021.1076.

Scott, James C. Moral Ekonomi Petani: Pergolakan Dan Subsistensi Di Asia Tenggara / James C. Scott; Diterjemabkan Oleh Hasan Basari; Disunting Oleh Bur Rasuanto. Jakarta: LP3ES, 1983.

—. Senjatanya orang-orang yang kalah: bentuk-bentuk perlawanan sehari-hari kaum tani. Jakarta: Yayasan Obor Indonesia, 2000.

The Moral Economy of the Peasant: Rebellion and Subsistence in Southeast Asia. Yale University Press, 1977.

Scott, Professor James C. Agrarian Studies: Synthetic Work at the Cutting Edge. Yale University Press, 2001.

Sugiyono. Metode penelitian pendidikan: (pendekatan kuantitatif, kualitatif dan R \& D). Bandung: Alfabeta, 2008.

Suharto, Edi. Kemiskinan Dan Perlindungan Sosial Di Indonesia: Menggagas Model Jaminan Sosial Universal Bidang Kesehatan. Cet. 1. Bandung: Alfabeta, 2009. 
Muhammad Aziz Khoiri, Leila Chamankhah

Suryana, A'an. "State Officials' Entanglement with Vigilante Groups in Violence against Ahmadiyah and Shi'a Communities in Indonesia." Asian Studies Review 43, no. 3 (July 3, 2019): 475-92. https://doi.org/10.1080/10357823.2019.1633273.

Widiyanto, W., Arya Hadi Dharmawan, and W. Nuraini. "Strategi Nafkah Rumahtangga Petani Tembakau Di Lereng Gunung Sumbing: Studi Kasus Di Desa Wonotirto Dan Desa Campursari, Kecamatan Bulu, Kabupaten Temanggung." Sodality: Jurnal Sosiologi Pedesaan 4, no. 1 (2010).

Yanto, Hanggarbini Sapta Wisuda. "Dampak Konflik Antar Aliran Agama (Studi Deskriptif Tentang Mekanisme Survival Para Pengungsi Keluarga Syiah Dalam Memenuhi Kehidupan Di Kabupaten Sampang)," n.d.

Yuana, Ambayu Sofya, Siti Kholifah, and Mohamad Anas. "Mekanisme Survival Petani 'Gurem' Pada Masa Pandemi COVID-19.” JSW (Jurnal Sosiologi W alisongo) 4, no. 2 (2020): 201-14.

Zattullah, Nour. "Konflik Sunni-Syiah Di Sampang Ditinjau Dari Teori Segitiga Konflik Johan Galtung." Jurnal Ilmu Budaya 9, no. 1 (2021): 86-101. 